\title{
Footprints of Climate Change on Fish Community of Mangrove Dominated Lower Gangetic Delta
}

\author{
Pavel Biswas $^{1}$, Tanmay Ray Chaudhuri ${ }^{1}$, Pallavi Dutta ${ }^{1}$, Manju Das1, Sufia Zaman ${ }^{1}$, Abhijit Mitra ${ }^{2 *}$ \\ ${ }^{1}$ Department of Oceanography, Techno India University West Bengal, Salt Lake Campus, Kolkata, India \\ ${ }^{2}$ Department of Marine Science, University of Calcutta, Kolkata, India.
}

"Corresponding author: Abhjit Mitra, Faculty Member, Department of Marine Science, Calcutta University 56B Belgachia Road, Duttabagan Bijoli Dutta Lane Kolkata 700 037, West Bengal, India. Tel: +91 9831269550; Email: abhijit_mitra@hotmail.com

Citation: Biswas P, Chaudhuri TR, Dutta P, Das M, Mitra A, et al. (2017) Footprints of Climate Change on Fish Community of Mangrove Dominated Lower Gangetic Delta. J Fish Aqua Dev: JFAD-124. DOI:10.29011/JFAD-124/100024

Received Date: 15 September, 2017; Accepted Date: 21 September, 2017: Published Date: 29 September, 2017

\section{Climate Change and Mangrove Fish Commu- nity: A noted area of interest}

Climate change is an inevitable truth of the present era. Global, regional and local effects of climate change on biotic community are ultimately the sum of processes which act on individual organisms. Perceptible changes are evident in the past few decades in the climate of the planet Earth as manifested by increase in air and water temperature. This has triggered the alteration of salinity profile in marine and estuarine compartment, and more specifically at the river mouth and estuarine systems that are connected to glaciers. The fish communities thriving in these dynamic systems shift or orient (Adapt) themselves in response to ecological conditions.

\section{Scenario of Indian Sundarbans in the lower Gangetic delta}

The mangrove ecosystem of Indian Sundarbans is an ideal zone for such study as the western and central sectors of the deltaic lobe are drastically different from each other with respect to salinity owing to the connections of the rivers in the western zone (Hugli and Mooriganga) with the Himalayan glaciers. Construction of the Farakka barrage on the Ganga River in April, 1975 to augment water supply to the Calcutta port has brought about a significant increase in freshwater discharge in its distributary, the Hugli estuary. The rivers in the central sector on the other hand have lost their connections with Ganga-Bhagirathi system in course of time and are now tide-fed in nature. The average salinity in the western sector of Indian Sundarban ranges from 6-25 psu which is far less than the salinity observed in the central sector (average salinity 10 - 29 psu) considering the yearly average data of 2014-2015 (Mitra and Zaman, 2014; Mitra and Zaman, 2015) [1,2]. This variation probably caused a compositional variation in fish community. The western sector showed the presence of more economically important fish species in comparison to trash fishes that may be attributed to decreasing trend of salinity in this zone (Table 1) in recent times.

\begin{tabular}{|c|c|c|c|c|}
\hline Place & $\begin{array}{c}\text { Pre Farakka } \\
(\mathbf{1 9 6 0 - 6 1 )}\end{array}$ & $\begin{array}{c}\text { Post Farakka } \\
\mathbf{( 1 9 8 5 )}\end{array}$ & $\begin{array}{c}\text { Post Farakka } \\
\mathbf{( 1 9 9 5 )}\end{array}$ & $\begin{array}{c}\text { Post Farakka } \\
\mathbf{( 2 0 0 5 ) *}\end{array}$ \\
\hline $\begin{array}{l}\text { Kakdwip } \\
\text { (western) }\end{array}$ & 32.80 & 15.10 & 13.93 & 8.56 \\
\hline $\begin{array}{c}\text { Canning } \\
\text { (central) }\end{array}$ & 28.00 & 28.90 & 26.70 & 11.34 \\
\hline
\end{tabular}

Table 1: Salinity (in psu) variation in Indian Sundarbans after the commissioning of the Farakka barrage. 


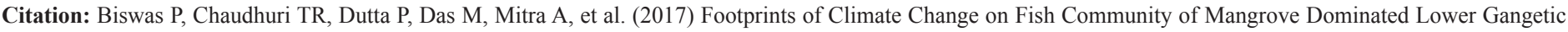
Delta. J Fish Aqua Dev: JFAD-124.

In the central sector, the ingression of seawater and resultant salinity increase has completely reversed the picture with more quanta of trash fishes in comparison to economically important species (Table 2).

\begin{tabular}{|c|c|c|c|c|}
\hline Station & Commercial variety & $\begin{array}{c}\text { H of Commercial variety } \\
\text { (sample size }=200 \mathrm{Kg} \text { ) }\end{array}$ & Trash variety & $\begin{array}{c}\text { H of Trash variety } \\
(\text { sample size }=100 \mathrm{~kg})\end{array}$ \\
\hline \multirow{7}{*}{$\begin{array}{c}\text { Kakdwip } \\
\text { (in western Indian Sundar- } \\
\text { bans) }\end{array}$} & Pama pama & & Thryssa $\mathrm{sp}$ & \\
\hline & Polynemus paradiseus & 3.098 & Stolephorus sp. & 1.786 \\
\hline & Ariusjella & & Harpodon neherius & \\
\hline & Tenualosailisha & & Cynoglossus sp. & \\
\hline & Sillaginopsispanijus & & & \\
\hline & Osteogeneious militaris & & & \\
\hline & Polydactylus indicus & & & \\
\hline & Pama pama & & Thryssa sp & \\
\hline & Polynemus paradiseus & 1.896 & Stolephorus sp & 3.995 \\
\hline & Arius jella & & Harpodon neherius sp & \\
\hline & Sillaginopsis panijus & & Cynoglossus $\mathrm{sp}$ & \\
\hline
\end{tabular}

Table 2: Mean value of Shannon Weiner Species Diversity Index (H) computed from one-year survey (18.03.2016 to 21.02.2017) on fish catch by local fisherman in Indian Sundarbans.

Source: Sanyal et al. (2007) [3], In: Sunderban Wetlands (edited by Dr. Madhumita Mukherjee); published by Department of Fisheries, Aquaculture, Aquatic resources and Fishing Harbour, Govt. of West Bengal; *survey conducted by the authors.

We computed the Shannon Weiner Species diversity index (H) with the collected samples (collection time was 18.03.2016 to 21.02.2017) for both commercial and trash varieties with a sample size of $200 \mathrm{~kg}$ and $100 \mathrm{~kg}$ for commercially important and trash fishes respectively and documented more diversity of trash fishes in the central sector, which may be attributed to intrusion of saline water from the adjacent Bay of Bengal region in the south preferably during the high tide.

\section{Reason for Compositional Change in Fish Com- munity}

The rate of climate change as seen from the present study may thus be a major determinant of the abundance and distribution of new populations. Rapid change from physical forcing usually will favour production of smaller, low-priced, opportunistic species that discharge large numbers of eggs over long periods (IPCC, 1996) [4]. Reports of decline of species numbers in fish due to increase of salinity have been published by several workers (Carpelan, 1967 [5]; Copeland, 1967 [6]; Hammer, 1986) [7]. The main causes behind the alteration of fish community structure (preferably the increase in the abundance and diversity of trash fishes) due to increase in salinity (a consequence of seawater ingression because of warming effect) are:

- Reproductive failure of fishes thriving in hyposaline environment (mostly commercially important fishes)
- Interaction of other environmental parameters with salinity to cause excessive mortality (synergistic effect) of commercially important fishes that prefer hyposaline condition

- Loss of primary food supply due to exceedance of salinity tolerance for that organism, and,

- Direct mortality of hyposaline water loving fishes due to exceedance of salinity tolerance

In the western sector of Indian Sundarbans, lowering of salinity due to supply of fresh water through Hugli (after the commissioning of the Farakka barrage) has made the environment congenial particularly for fish like Hilsa (Tenualosa ilisha). The landing volume of fish has also increased during the post-Farakka period (Sinha et al., 1996) [8]. The preference of commercially important fishes like Hilsa (Indian Shad) for hyposaline environment can be confirmed from the excessive catch during September 2017. This may be correlated with the dilution factor of western part of Indian Sundarbans that has increased (0.98) due to excessive rainfall in August and September, 2017 (average rainfall recorded during 15th August to 13th September 2017 is $349 \mathrm{~mm}$ ) (Current Results weather and science facts) [9]. A long-term study of several years is, however, needed to discriminate the seasonal effect (feature) of fish diversity due to impact of salinity fluctuation in the framework of present geographical locale.

\section{Acknowledgement}

The authors acknowledge the support of the project entitled “...Vulnerability Assessment and development of adaptation strategies for Climate Change impacts with special reference to coasts and island ecosystems of India (VACCIN)...." funded by CSIR 
Citation: Biswas P, Chaudhuri TR, Dutta P, Das M, Mitra A, et al. (2017) Footprints of Climate Change on Fish Community of Mangrove Dominated Lower Gangetic Delta. J Fish Aqua Dev: JFAD-124.

for undertaking the experimental works on the seedling samples collected from the islands of Indian Sundarbans.

\section{References}

1. Mitra A, Zaman S (2014) Carbon Sequestration by Coastal Floral Community; published by The Energy and Resources Institute (TERI) TERI Press, India; Copyright The Energy and Resources Institute.

2. Mitra A, Zaman S (2015) Blue Carbon Reservoir of the Blue Planet. Published by Springer.

3. Sanyal P, Mukherjee M, Das KL (2007) Status of Sharks, Rays and Dolphins of Sunderbans with special views on Marine Reserve. In: Sunderban Wetlands (Edited by Dr. Madhumita Mukherjee) Published by Department of Fisheries, Aquaculture, Aquatic Resources and Fishing Harbours, Govt. of West Bengal: 256.

4. IPCC (1996) The Regional Impacts of Climate Change. WG II, Chapter 6. Executive Summary.
5. Carpelan LH (1967) Invertebrates in Relation to Hypersaline Habitats. Invertebrates in Super saline waters. University of Texas Contribution Marine Science 12: 219-229.

6. Copeland BJ (1967) Environmental Characteristics of Hypersaline Lagoons. University of Texas Contribution Marine Science 12: 207-218.

7. Hammer UT (1986) Saline Lake Ecosystems of the world. Dr. W Junk Publishers. Dordrecht, The Netherlands.

8. Sinha M, Mukhopadhyay MK, Mitra PM, Bagchi MM, Karmakar HC (1996) Impact of Farakka Barrage on the Hydrology and Fishery of Hooghly Estuary. Estuaries 19: 710-722.

9. Current Results weather and science facts (1990) Average Rainfall for India in August. 